\title{
Assessing a first-to-file patent system
}

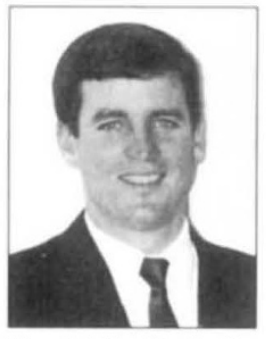

Daniel P. Burke is a patent attorney in Jericho, $N Y$.

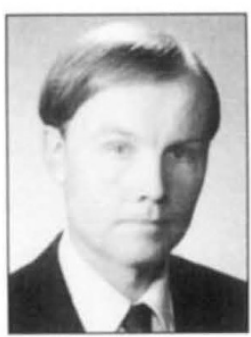

Kevin J.McGough is a patent attorney with a multinational pharmaceutical company.
Pending legislation will change the U.S. first-to-invent patent system to a first-to-file system. While such a modification will necessitate changes in the way inventors think as they seek to protect their rights, in practice the ultimate allocation of patent rights would not change if this legislation is enacted.

The U.S. is the only major industrial nation that retains a first-toinvent patent standard. Its major trading partners have made the success of intellectual-property-harmonization treaty negotiations contingent upon U.S. adoption of first-to-file patent protection. Last September an advisory commission appointed by the Patent and Trademark Office (PTO, Arlington, VA) recommended adoption of a first-to-file system.

Representatives of small manufacturers and university researchers criticized first-to-file patent protection at a Congressional hearing on the pending legislation held last April. They argued that small companies and universities lack the re- sources to compete in a race to PTO with multinational corporations and that they are frequently engaged in seminal research of uncertain utility that does not favor quick patent filing.

Are these criticisms well taken and is first-to-file patent protection bad for the typically small-sized biotechnology company? The answer is probably no, as a closer inspection of the proposed revisions reveals.

The Patent System Harmonization Act of 1992 would change the U.S. law to a first-to-file system with a 20-year patent term. Prior use rights for those who independently develop an invention before it is patented by another would also be implemented under the act.

These changes have been elaborated on by the PTO advisory commission. It advocates authorization of a low-cost, "informal" provisional application that could be filed without claims and that would only have to describe how to make and use the invention. After filing such a provisional application, the applicant would then have one year in which to file a complete application including patent claims, and the 20 year patent term would run from the date of filing of the complete application. A one-year grace period would allow an applicant to publish an invention one year prior to filing a patent application, and the commission favors the adoption of a legal presumption that a subsequent pre-filing publication by a third party is derived from original the applicant's publication. A third party, therefore, could not prevent issuance of a patent to an applicant who published during the grace period by also publishing during that time.

In a controversial and remarkable departure from current law, the act and commission would allow prior use of the invention, even if secret, by a third party to continue subsequent to issuance of a patent. To escape liability, the prior use must be in the U.S., must not have been derived from the applicant, must be

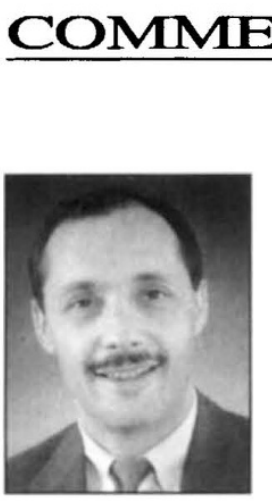

Josef von Rickenbach is chairman and chief executive officer of Parexel International (Waltham, MA).

\section{CBER narrows the product-review pipeline}

An even 40 years after Francis Crick and James Watson discovered the double helix, the Food and Drug Administration (FDA, Bethesda, MD) is busily re-inventing itself to accommodate the therapeutic applications of this discovery. When FDA's Center for Biologics Evaluation and Research (CBER) relocates most of its nonresearch staff to new quarters this month, a new era of biologics regulation will begin. Specifically, CBER will begin "functional operations" under a center-wide restructuring initiative designed to streamline new product reviews. The center will also accelerate efforts to increase its staffing by as much as 50 percent, an initiative to be funded directly by industry through user fees.

But the wealth in terms of faster approvals will not necessarily be distributed evenly throughout the biotechnology industry. We must all understand that, in shortening the pipeline, CBER will recast that pipeline in one other fundamental way: the center will narrow it. The reason: to significantly reduce approval times, CBER will first and foremost need to focus its resources. And the target of this increased focus will be products whose sponsors have conducted quality research-and-development programs and assembled quality premarketing submissions. CBER officials will no longer invest limited resources in reviewing submissions with deficiencies of any significance.

Indeed, FDA has committed to extremely specific and aggressive performance goals in reviewing both drugs and biologics. And these are not just long-term goals. Beginning with applications submitted this September, FDA has made the following commitments:
-To act, within six months of submission, on 55 percent of complete product license applications (PLAs) for products appearing to represent a therapeutic advance.

-To act, within 12 months of submission, on 55 percent of complete PLAs for products with therapeutic capabilities similar to marketed drugs and PLA supplements with clinical data.

-To act, within six months of resubmission, on 55 percent of complete PLAs resubmitted after the sponsor receives a non-approval letter.

-To act, within six months of submission, on 55 percent of manufacturing supplements and other supplements not requiring the review of clinical data.

And these percentages increase annually, up to 90 percent in 1997.

Some will point out that CBER is required only "to act" on applica- 
an actual use or a substantial preparation, cannot expand in scope after patent issuance, and may require payment of royalties in certain situations. These prior use rights could not be sold or otherwise transferred. Under the pending legislation, a patent application would be published within 18 months of filing, as in Europe and Japan. The commission advocates publication 24 months after filing, because it is doubtful that PTO could examine an application within 18 months, and because an applicant should have the option to withdraw an application based on an examination prior to publication. An infringer would be liable for damages from the date of written notification of infringement after publication.

Finally, the PTO advisory commission recommends that if the U.S. adopts a first-to-file patent scheme, U.S. patents should be available as prior art for novelty purposes as of their earliest effective filing date, including a foreign priority date. They would be available as prior art for obviousness purposes as of their U.S. filing date, including the date of any provisional application.

In reality, the majority of U.S. patents are awarded to inventors who are both the first to invent and the first to file. Of the approximately 130,000 U.S. patent applications filed annually, only about 300 end up in interference proceedings to determine if the applicant who was the first to file was in fact the first inventor. In 75 percent of those interferences, the patent is awarded to the first-to-file applicant. For example, Hoffmann-La Roche (Nutley, NJ) recently failed to persuade the PTOBoard of Patent Appeals and Interferences that it was entitled to patent claims to a monoclonal antibody to interferongamma, notwithstanding the fact that another party had an earlier effective patent-filing date. Similarly, Amgen (Thousand Oaks, CA) was the first to file a patent application directed toward DNA sequences encoding erythropoietin and refuted Genetics Institute's (Cambridge, MA) assertion that it was the first to invent the methodology to clone such sequences, and that Amgen's patent claims were, tions within these time frames and that it can still afford to accept PLAs of varying quality and simply deny approval upon the deadline's arrival. Such practices would fulfill the letter at the sacrifice of the spirit of the law. And CBER officials know it.

In fact, CBER officials recently announced that within 45 days of receiving a PLA, CBER will screen the submission todetermine whether it should enter the review pipeline or be sent back to its sponsor for reworking. In previous times, CBER may have tended to accept some deficient PLAs with the understanding that the sponsor would address the deficiencies before they impaired the review process. But with review deadlines-and significant political pressure to meet them-CBER will no longer be as willing to gamble on companies's abilities to fulfill postsubmission promises. When companies cannot, these obligations will become CBER's own. therefore, unpatentable as obvious.

While the presidential election and uncertainty over the outcome of international patent-harmonization negotiations could slow the domestic patent-harmonization initiative, it is almost inevitable that the U.S. will have to concede its first-toinvent patent scheme to achieve much needed uniformity in worldwide intellectual-property protection. Biotechnology inventors should "make haste, slowly" if the U.S. adopts a first-to-file system.

It may be advisable for companies and universities to instruct senior scientists and group managers not to delay in filing the low-cost provisional applications. Such filings could be made once a clear disclosure on how to make and use the invention can be prepared. With proper management and monitoring of these provisional applications, the following 12 months can be utilized by upper management and patent-law professionals to determine whether the expense of filing a "complete" application is justified by the potential rewards.As with the present system, the organizations that take the time to learn some basics about protecting their rights will reap far more than those who lose valuable rights through carelessness or misunderstandings about the law.

Viewed defensively from a corporate perspective, prior-use rights will require a careful monitoring of the scope of commercial activities, including licensing, to ensure that patents subsequently issued to third parties are not in fact blocking. The key inquiry will be what was done before and after the filing date of the third-party's patent.

WhetherU.S. inventors will thrive under a first-to-file system will ultimately depend upon the resources allocated to the PTO by Congress to ensure its ability to cope with a two-stage filing scheme and complete a prior-art search before publication. With relatively minor increases to the PTO budget by Congress and a commitment by corporations and academia to provide some basic training to their professionals, the U.S. could harmonize its patent laws with those of the rest of the world.
Though a first-

\section{to-file patent}

system would

require changes

in the way

inventors protect

their rights, the

allocation of

patents wouldn't

change. 